\title{
KOMPENTENSI KOMUNIKASI ULAMA LINTAS BUDAYA
}

\author{
Wakidul Kohar \\ (Dosen IImu Komunikasi IAIN Imam Bonjol Padang. Email: koharwakidul@yahoo.co.id)
}

\begin{abstract}
Penelitian ini beranjak dari realitas bahwa komunikasi lintas budaya, sangat menentukan dalam penyelenggaraan program pelestarian nilai adat, budaya dan Agama di Nagari Lunang. Penelitian ini berkesimpulan bahwa perbedaan budaya berimplikasi terhadap komunikasi ulama lintas budaya. Hal itu dilatarbelakangi oleh: Pertama, Faktor pengetahuan (knowledge) yang terdiri dari Nilai-nilai budaya, pandangan dunia, sejarah, dan organisasi sosial, yang dianut masing-masing etnis, mempengaruhi kompetensi komunikasi ulama lintas budaya pada aspek pengetahuan dalam kontek pelestarian nilai budaya, adat dan agama. Secara konseptual, hasil penelitian ini mendukung teori komunikasi antarbudaya yang dikemukakan oleh William B. Gudykunst dan Young Yun Kim, bahwa dalam komunikasi antarbudaya manusia selalu dipengaruhi oleh sistem kultural, sosiokultural dan psikokultural. Kedua, Kemampuan mengurangi kesalahpahaman budaya merupakan faktor penghambat kompetensi komunikasi ulama lintas budaya pada aspek motivasi. Secara konseptual temuan penelitian ini, menguatkan teori Larry. A. Samovar, Richard E.Porter dan Edwin R. McDanel. Ketiga, Gaya komunikasi yang mau menang sendiri, defensive dan kurang ramah, merupakan factor penghambat pada aspek ketrampilan berkomunikasi ulama lintas budaya. Temuan ini mendukung teori negosiasi identitas yang dikemukan oleh William B.Gudykunts.

Sumber data dalam penelitian ini adalah data kualitatif. Dengan alasan bahwa komponen-komponen data yang dicari meliputi aspek kehidupan masyarakat, yaitu apa yang dikatakan dan dilakukan oleh para informan, maka segenap komponen tersebut di baca dianalisis dengan teori komunikasi antarbudaya
\end{abstract}

Kata Kunci: Kompetensi, Komunikasi, Ulama Lintas Budaya

\section{PENDAHULUAN}

Sumetera Barat, sebagai salah satu propinsi di Indonesia, dengan sosialisasi otonomi daerah, memunculkan berbagai persoalan yang hampir sama dengan daerah lain. Persoalan tersebut diantaranya aspek politik, social, ekonomi, dan komunikasi antarbudaya di beberapa Nagari. Sumatera Barat dengan sosialisasi otonomi daerah bermuara kepada beberapa kebijakan pemerintah daerah yang sangat berpengaruh terhadap kultur (nilai-nilai budaya), sosiokultural (pengalaman interaksi antara anggota budaya) dan psikokultural dalam kehidupan sosial di Sumatera Barat. Salah satu kebijakan pemerintah daerah
Sumatera Barat di era otonomi daerah adalah kembali kepada bentuk pemerintahan Nagari. Nagari adalah unit sosial-politik terdepan dalam sistem sosial dan politik tradisional masyarakat Minangkabau. Sistem ini telah ada di Sumatera Barat dengan liku-liku sejarah yang panjang sebelum dan sesudah kemerdekaan baik pada era Orde lama dan Orde Baru (Gusni Anan, 2003). Fenomena yang muncul, dibeberapa wilayah Sumatera Barat, adalah keinginan untuk memperluas wilayah nagari. Aspirasi masyarakat terus bermunculan, salah satunya adalah wilayah Lunang. Pengembangan nagari tersebut telah lama ditanggapi oleh Pemerintah Daerah Tk. II Pesisir Selatan, bahwa empat nagari di usulkan 
untuk pengembanganya pada wilayah Lunang, Tapan, Indrapura dan Kambang. Usulan dari masyarakat itu dibenarkan kerena sesuai dengan Perda N0.08/2007 tentang Pemerintahan Nagari yang berisi tentang dimungkinkan pengembangan Nagari dengan syarat-syarat tertentu. Hal ini diungkapkan oleh Kepala bagian Pemerintahan pada Sekretaris Daerah (Sekda) Kabupaten Pesisisir Selatan, Mawardi Roska (Singgalang, 30 November 2007). Pada akhirnya tahun 2012, terbentuk pemerinahan nagari, yang bernama nagari Lunang Barat, dengan Wali nagari bernama Rambat Mulyadi (Observasi, Maret 2012).

Dalam penyelenggaraan pemerintahan nagari, ada tiga program yang setidaknya menjadi perpanjangan program pemerintahan Propinsi Sumatera Barat. Di antara penyelengaraan tersebut adalah ; Pertama, penyelenggaraan Pemerintahan Nagari, kedua, program ekonomi dan pemberdayaan masyarakat dan ketiga, penyelenggaraan pelestarian nilai adat, budaya dan Agama. Di antara aspek yang menarik adalah program pelestarian nilai adat, budaya dan agama. Untuk pelaksanaan program ini, peran dan kemampuan ulama nagari dalam menyampaikan pesan-pesan tersebut sangat menentukan. Karena unsur pelestarian nilai adat, budaya dan agama, adalah satu satu faktor yang selalu dinilai kompetensinya oleh TIM independen dari Pemerintahan Propinsi Sumatera Barat, pada setiap tahunnya. Terkait dengan nagari Lunang Barat, yang didomisili oleh dua etnis Minang dan Jawa, merupakan masalah tersendiri bagi para ulama, untuk menyampaikan pesan-pesan, terkait dengan pelestarian nilai, adat, budaya dan agama pada masyarakat yang multi etnis. Secara umum dapat dikatakan, bahwa proses akulturasi masyarakat Lunang Barat, pada kenyataannya sampai saat ini masih menghadapi hambatan komunikasi lintas budaya. Interaksi sosial masyarakat, masih diwarnai prasangka antar etnis, sehingga menyulitkan pembentukan nagari Lunang yang inklusif. Hal tersebut juga menafsirkan bahwa makna ${ }^{1}$ kembali ke nagari, pelestarian nilai adat, budaya dan agama yang telah dipelajari oleh etnis Jawa melalui interaksi dengan etnis Minang etnis Jawa tidak merasakan yang lebih baik dalam sistem pemerintahan nagari yang berbasiskan budaya Minang.

Persoalan ini timbul karena proses komunikasi antar etnis, diwarnai oleh disintegrasi sosial di antara mereka yang memiliki latar belakang perbedaan budaya yang mengakibatkan problem komunikasi lintas budaya. Proses komunikasi sosiologis di wilayah ini, pada akhirnya mengalami hambatan. Hambatan tersebut dilatarbelakangi oleh perbedaan sistem budaya masing-masing etnis, hasil pengalaman komunikasi antaretnis, prasangka sosial, dan belum adanya kompetensi komunikator ulama dan komunikan lintas budaya, ${ }^{2}$ di wilayah nagari Lunang Barat. Kondisi ini muncul, karena pada saat yang sama, pihak-pihak yang berkomunikasi berusaha untuk mengomunikasikan identitasidentitas yang mereka inginkan dalam berinteraksi. Mereka berupaya untuk mempertentangkan atau mendukung identitas-identitas orang lain.

1. Tesis dari Interaksionisme Simbolik, bahwa berbagai makna tentang sesuatu, dipelajari oleh seseorang melalui interaksi di antara mereka. Makna muncul dari adanya pertukaran simbol-simbol dalam kelompok sosial (Stephen W. Litteljonh, 1996).

2. Ukuran kompentensi seorang komunikator dan komunikan dalam setiap konteks komunikasi adalah pertama, memiliki motivasi untuk selalu berkomunikasi dengan orang lain, dalam arti motivasi mengurangi kesalahpahaman budaya; kedua, mempunyai keinginan untuk mempelajari budaya orang lain; ketiga, mempunyai usaha untuk menambah keterampilan berkomunikasi dengan orang lain (B. Spitzberg and W. Cupach, 1984). 
Dengan kata lain terjadi suatu proses negosiasi identitas yaitu proses interaksi transaksional antara ulama dan masyarakat dalam situasi antarbudaya. Dengan demikian, beranjak dari asumsi bahwa setiap masyarakat majemuk akan menghadapi masalah komunikasi lintas dan antarbudaya dalam setiap konteksnya. Mengingat di Nagari Lunang belum terdapat bangunan komunikasi ulama dengan mad'u atau masyarakatnya yang lintas dan antar budaya, sementara disisi lain terdapat tingkat heterogenitas di masyarakat Lunang. Atas alasan tersebut artikel ini ditujukan untuk menjelaskan kompentensi komunikasi ulama lintas budaya dalam konteks pelestarian nilai adat, budaya dan agama dengan mengurai tiga pertanyaan: 1) Bagaimana kompetensi komunikasi ulama lintas budaya pada aspek pengetahuan dalam konteks pelestarian nilai adat, budaya dan agama; 2) Bagaimana kompetensi komunikasi ulama lintas budaya pada aspek motivasi dalam konteks pelestarian nilai adat, budaya dan agama; 3) Bagaimana kompetensi komunikasi ulama lintas pada aspek ketrampilan komunikasi dalam konteks pelestarian nilai adat, budaya dan agama?.

Penelitian ini mengunakan paradigma naturalistik. Paradigma ini digunakan sebagai gantungan ilmiah dalam melihat realitas di lokasi penelitian (Endraswara, 2006). Pilihan terhadap paradigma ini didasari dan terkait dengan jenis permasalahan yang sedang dipertanyakan, yaitu bagaimana perbedaan budaya yang dimiliki oleh ulama berimpliksi terhadap komunikasi lintas budaya di Nagari Lunang Barat. Agar penelitian ini menjadi lebih terarah maka penelitian ini menggunakan metode dan pendekatan kualitatif.

\section{MEMBACA KOMPETENSI KOMUNIKASI ULAMA LINTAS BUDAYA}

Dinamika masyarakat di Nagari Lunang pada era otonomi daerah mempunyai warna khusus dibanding dengan kondisi sosial nagari-nagari lain di wilayah Sumatera Barat. Nagari Lunang memiliki struktur masyarakat majemuk yang dapat berpengaruh terhadap proses komunikasi antarbudaya di era otonomi daerah. Uraian berikut adalah gambaran bagaimana situasi suku bangsa yang berbeda budaya berkomunikasi dalam kontek kompetensi komunikasi ulama lintas budaya.

\section{Ulama Lintas Budaya; Kompetensi Komunikasi Aspek Pengetahuan Dalam Konteks Pelestarian Nilai Adat, Budaya dan Agama}

Minangkabau ditinjau dari sudut sosial budaya, tidak sama dengan Sumatera Barat sekarang. Secara sosial budaya, Minangkabau meliputi daerah budaya Riau dan sebagian wilayah budaya Jambi. Secara historiografi tradisional, Minangkabau mencakup dua jenis daerah. Pertama, daerah darek (darat) yang merupakan daerah asal Minangkabau, terdiri dari tiga Luhak yaitu Luhak Agam (daerah sekitar Bukittinggi), Luhak Tanah Datar, (meliputi wilayah Batusangkar), dan Luhak Lima Puluh Kota (meliputi daerah sekitar Payakumbuh). Kedua, daerah rantau yaitu daerah yang merupakan perluasan pemukiman masyarakat Minangkabau pada masa perkembangannya, terletak di seputar daerah darek. Untuk daerah Luhak Lima Puluh Kota, rantaunya mulai dari Bangkinang, daerah aliran sungai Kampar Kanan, Kampar Kiri, Rokan dan Siak Indragiri. Sedangkan rantau untuk Luhak Agam adalah daerah Pasaman mulai dari 
Lubuk Sikaping, Pantai Air Bangis, Tiku, dan Pariaman. Daerah Rantau untuk Luhak Tanah Datar adalah Pantai Padang, terus ke selatan sampai ke "Indrapura," Tapan-Lunang. Daerah Kerinci dan Muara Labuh. Dari daerah Indrapura ke selatan, dijumpai wilayah Lunang (Taufik Abdullah, 1972).

Berkaitan dengan sejarah etnis Minang di Nagari Lunang, informasi yang diberikan oleh informan-informan etnis Minang dan pengetahuan tentang sejarah Lunang yang diperoleh dari tokoh masyarakat Minang dan Jawa, serta yang sering dikomunikasikan, menyebutkan bahwa peradaban etnis Minang pribumi dimulai di wilayah Lunang, semenjak zaman kerajaan Minangkabau ada. Keberadaan ini bersamaan dengan Kerajaan Pagaruyung, Indragiri, dan Mande Rubiah di Lunang (Nagari saat ini). Seiring dengan perjalanan sejarah, kerajaan di Minangkabau termasuk di Lunang mengalami masa kehancuran, sehingga kerajaan tersebut hanya berupa dinasti sebagaimana kerajaan-kerajaan lain di Nusantara. Silsilah ratu Mande Rubiah yang merupakan dinasti kerajaan di Lunang tidak terungkap data silsilah keturuan yang lengkap, hanya saja menurut infomasi yang diperoleh dari para informan, bahwa "Mande" yang masih hidup hingga kini, adalah Mande Rubiah keturunan yang ke-VII. Selanjutnya, informasi yang dapat dikumpulkan, baik dari ulama, dan berbagai informan, bahwa peradaban dan kehidupan masyarakat Minang pribumi, hingga saat ini tetap menempati lokasi sekitar rumah gadang atau dinasti kerajaan Mande Rubiah.

Istilah etnis Minang pendatang, adalah etnis Minang yang berasal dari berbagai daerah yang masih satu kabupaten. Berdasarkan data transmigrasi yang dirilis oleh pemerintahan Kecamatan Lunang Silaut, etnis tersebut datang ke Nagari Lunang dengan keinginan sendiri sebagai transmigran lokal. Mereka sebenarnya juga masyarakat asli Minangkabau, namun mereka berasal dari luar nagari Lunang. Mereka mendiami wilayah nagari Lunang ini bersamaan dengan program transmigrasi umum yang diselenggaran oleh pemerintah pada tahun 1974 (Data Transmigrasi, 1989).

Dari uraian di atas, argument teoritisnya, bahwa pengetahuan tentang budaya,yang dimiliki oleh para ulama, tokoh adat dan masyarakat, baik terkait dengan kesamaan persepsi tentang sejarah budaya masing-masing etnis, dapat mendukung terkait dengan pelestarian nilai nilai budaya, adat dan agama di wilayah ini.

\section{Kompetensi Komunikasi Ulama Lintas Budaya Pada Aspek Motivasi Dalam Konteks Pelestarian Nilai Adat, Budaya dan Agama}

Kompetensi motivasi pada penelitian ini adalah sejauhmana ulama di Nagari Lunang berkeinginan untuk berinteraksi, mengurangi kesalah pahaman budaya, mendialogkan dan bernegosisai antara budaya yang dimilikinya, dengan budaya oranng lain. Pada tataran konsep, antara budaya Minangkabau dan budaya Jawa memiliki dasar yang berbeda dan tampak bertolak belakang, tetapi menurut para ulama atau tokoh agama ada aspek kesamaan nilai budaya, yang tampak dalam interaksi sosial di nagari Lunang. Sumber konsep adat Minangkabau berasal dari dari 10 pokok perkara yang menjadi landasan untuk membangun masyarakat berdasarkan ABS-SBK (Myrtha Soeroto, 2011). Sedangkan 
etnis Jawa di lokasi ini pada umumnya budaya mereka bersumber dari Tantularisme dan juga dari narasi besar (grand naratif) "pewayang" dalam Mahabrata (Tamzirien, 2008). Persamaan dalam nilai-nilai dari kedua budaya tersebut dapat dilihat dalam interaksi sosial para tokoh agama dan dianalisis berdasarkan teori komunikasi antarbudaya. Temuan ini mengambarkan kompetensi ulama pada aspek motivasi dalam mengurangi kesalahfahaman budaya yaitu: Pertama, individualisme dan kolektivisme. Salah satu dimensi paling fundamental yang membedakan budaya adalah tingkat individualisme dan kolektivisme. Dimensi ini menentukan bagaimana orang hidup bersama, dan nilai-nilai mereka, dan bagaimana mereka berkomunikasi (Yoko Matsumo et al., 1996). Kajiannya tentang individualisme dalam lima puluh tiga negara, negara yang paling individualistik secara berurutan adalah Amerika, Australia, Inggris, Kanada, dan Belanda yang semuanya negara Barat atau Eropa. Negara yang paling rendah tingkat individualismenya adalah Venezuela, Kolombia, Pakistan, Peru, dan Taiwan yang semuanya budaya Timur atau Amerika Selatan. Korea berurutan ke43 dan Indonesia berurutan ke-47 (Kim Geung, 2004). Tingkat yang menentukan suatu budaya itu individualistik atau kolektivistik mempunyai dampak pada perilaku nonverbal budaya tersebut dalam berbagai cara. Orang-orang dari budaya individualistik relatif kurang bersahabat dan membentuk jarak yang jauh dengan orang lain. Budaya-budaya kolektivistik saling tergantung, dan akibatnya mereka bekerja, bermain, tidur, dan tinggal berdekatan dalam keluarga besar atau etnis.

Kolektivitas komunitas Minang, dipahami oleh ulama nagari Lunang diantaranya ditandai/ disimbolkan dengan "rumah gadang," karena di wilayahnya selalu menyaksikan rumah gadang Mande rubiah, sedangkan bagi masyarakat Jawa menurutnya, kelektivitas tertuang dalam filosofi simbol" mangan ora mangan ngumpul'3 (Hasan Muarif Ambary, 1998). Informasi yang dapat dijaring dari berbagai sumber dan informan, para ulama atau tokoh agama telah menunjukkan rasa kebersamaan dituangkan dalam perilaku seharihari dengan cara mencari titik persamaan terhadap budaya yang berbeda; Kedua, feminin dan maskulin. Maskulinitas adalah dimensi budaya yang sering terlupakan. Ciri-ciri khas maskulin biasanya dihubungan dengan kekuatan, ketegasan, persaingan, dan ambisi, sedangkan ciri-ciri khas feminin dihubungkan dengan kasih sayang, pengasuhan, dan emosi. Penelitian antarbudaya menunjukkan bahwa anak perempuan diharapkan lebih dapat mengasuh daripada anak laki-laki walaupun ada variasi yang cukup banyak dari negara yang satu dengan yang lain (William B. Gudykunst et al., 1996).

Sedangkan budaya feminin lebih mementingkan perasaan. Maskulinitas suatu budaya dihubungkan secara negatif dengan persentase wanita dalam pekerjaan teknis dan profesional serta dihubungkan secara positif dengan pemisahan kedua jenis kelamin dalam pendidikan tinggi. Sebagian ulama di wilayah ini berusaha untuk menggabungkan pemahaman terkait dengan hal tersebut. Budaya Jawa simbol, menurut sebagian mereka, bahwa istri adalah "konco wingking" dalam artikata wanita masih sub ordinat, sementara di Minang walaupun ada

3. Mangan ora mangan ngumpul mengambarkan tingkat kuatnya ikatan kekerabatan Jawa dan kuatnya keterikatan mereka terhadap tanah kelahiran tempat mereka hidup, beranak-pinak dan memperoleh makan. 
"bundo kanduang" akan tetapi kekusaan tetap jatuh kepada mamak artinya laki-laki, karena posisi bundo kanduang sebagai sunting dalam nagari, hiasan dalam sebuah nagari, kalau hiasan berarti hanya sebagai pelengkap; Ketiga, kesenjangan kekuasaan. Dimensi fundamental selanjutnya dalam perspektif komunikasi antarbudaya adalah kesenjangan kekuasaan. Kesenjangan kekuasaan telah diukur dalam banyak budaya menggunakan indeks kesenjangan kekuasaan (IKK) (William B. Gudykunst dkk, ed., 1989). Budaya dengan nilai IKK tinggi mempunyai kekuasaan dan pengaruh yang lebih terpusat pada sekelompok orang daripada terbagi dengan cukup merata di seluruh penduduk. IKK sangat berkaitan dengan otoritarianisme. Negara dengan IKK tertinggi adalah Filipina, Meksiko, Venezuela, India, dan Singapura. Negara-negara tersebut semuanya negara-negara Asia Selatan atau Karibia, kecuali Perancis. Negara dengan IKK terendah (mulai dari yang paling rendah) adalah Austria, Israel, Denmark, Selandia Baru, dan Irlandia. Dalam hal ini, Indonesia terletak ditingkat ke-8 yang sangat tinggi. Sistem sosial dengan perbedaan kekuasaan juga menghasilkan perilaku kinesik yang berbeda. Dalam keadaan beda kekuasaan, bawahan sering tersenyum dalam usaha untuk tampak sopan dan menenangkan atasan. Garis lintang dan iklim merupakan kekuatan utama dalam membentuk budaya (Larry A Samovar et al., 2007).

Kebudayaan yang sangat menjunjung tinggi kesenjangan kekuatan besar selalu menekankan nilai ketidakseimbangan atas status-status individu. Senyum yang terus menerus yang dilakukan orangorang Timur mungkin merupakan usaha untuk menenangkan atasan atau menghasilkan hubungan sosial yang lebih mulus mungkin berhasil dinaikkan jabatannya dalam budaya ber-IKK tinggi. Usaha untuk mengurangi kesalahpahaman budaya yang berbeda, para ulama berpendapat bahwa filosofi Minang tentang kepemimpinan dan kekuasaan adalah didahulukan selangkah dan ditinggikan seranting, apabila pemimpin sudah memberikan makmulat harus didukung bersama, sementara filosofi budaya Jawa menganut sistem pandito ratu, dalam arti punya loyalitas tinggi terhadap kekuasan dan pemimpin.

Keempat, sopan santun dan kebiasaan. Sopan santun merupakan jalan bagaimana seseorang dapat mendisiplinkan diri mereka dan bagaimana dapat diterima dalam menjalin suatu hubungan dengan orang lain. Budaya Minang, rasa hormat dan sopan santun menjadi aspek penting dalam kehidupan. Etika kerukunan dan kehormatan menjadi aspek penting dalam pergaulan. Seseorang diharapkan agar tidak memicu konflik dalam bersikap, dan dalam cara berbicara serta membawa diri dituntut untuk selalu menunjukan sikap hormat terhadap orang lain sesuai dengan derajat dan kedudukannya. Pendapat sebagian besat para ulama atau tokoh agama, bahwa orang Minang menjunjung tinggi senioritas, sedangkan di Jawa lebih menekankan status. Baik etnis Minang maupun Jawa, menurutnya mengetahui secara rinci mengenai lawan bicara adalah hal yang wajar dalam pembicaraan. Hal ini dimaksudkan untuk mengetahui status lawan bicara dan bagaimana kita bersikap. Menolak untuk memberi jawaban juga bukan merupakan hal yang tidak sopan jika kita melakukannya dengan sikap sopan pula. Orang Minang dan orang Jawa pada dasarnya adalah orang yang ramah. Akan tetapi, orang Minang tidak begitu mudah mengekspresikan perasaan mereka dan sangat membatasi untuk 
jabat tangan untuk seseorang yang belum dikenalnya. Ketika bertemu dengan seseorang, orang Minang hanya mengangguk secara sopan atau berjabat tangan, kecuali dengan teman dekat. Berjabat tangan dengan wanita adalah hal yang biasa sebagaimana etnis Jawa, akan tetapi, bila seseorang telah mengenal orang Minang dengan dekat, rasa kekeluargaan akan lebih terasa, dan akan lebih sering berjabat tangan antarteman atau antarkenalan, bahkan melebihi keluarga.

Kelima, sopan santun di muka umum. Sopan santun termasuk indikator budaya yang paling sederhana untuk mendeskripsikan budaya. Menurut ulama atau tokoh agama di wilayah ini, sebagaimana yang mereka alami sehari- hari, bahwa etnis Jawa dan Minang, membuang ingus maupun bersendawa di depan umum adalah hal yang tidak sopan. Bagi etnis Minang, mendorong-dorong dari belakang ketika berada di tempat ramai adalah hal yang biasa walaupun tidak boleh menurut orang tua mereka. Akan tetapi, bila ini dilakukan dilingkungan etnis Jawa, kadang bisa menyulut keributan. Apabila seseorang bermaksud untuk lewat atau terburuburu, perlu untuk mengucapkan kata "nuwun sewu" dalam arti mohon permisi. Masih menurut mereka, baik etnis Minang dan Jawa tidak sopan dan tidak wajar jika laki-laki saling berangkulan atau wanita saling bergandengan tangan, walaupun kenyataanya tidak selalu demikian; Keenam, kebiasaan yang berhubungan dengan senioritas. Pendapat sebagian besar, para tokoh agama dan ulama di Nagari Lunang, orang Jawa maupun Minang, sangat menghormati orang tua. Seseorang tidak boleh berbicara sambil membelakangi atau menatap mata mereka ketika berbicara, karena hal ini tidak sopan. Bila menerima atau memberikan sesuatu kepada orang tua, kita harus menggunakan kedua tangan kita. Baik etnis Minang dan etnis Jawa dalam hal berjabat tangan, orang yang lebih muda yang mengajak berjabat tangan. Kemudian, orang Jawa bila berjalan di hadapan orang yang lebih tua agak membungkukkan badan, sedangkan etnis Minang tidak harus terlalu membungkuk.

\section{Kompetensi Komunikasi Ulama Lintas Budaya Pada Aspek Keterampilan Berkomunikasi Dalam Konteks Pelestarian Nilai Adat, Budaya dan Agama.}

Maksud kompetensi ketrampilan berkomunikasi pada penelitian ini, adalah bagaima gaya komunikasi tokoh agama atau ulama, ketika meyampaikan pesan atau memberikan respon terhadap perbedaan ekpresi budaya dan agama, dalam konteks pelestarian nilai adat, budaya dan agama. Tipologi keterampilan tersebut dapat dilihat pada: pertama, gaya komunikasi yang dilakukan oleh tokoh agama atau ulama yang cenderung menggunakan strategi mengusai lawan bicara dengan etnis yang berbeda budaya. Hal ini dirasakan oleh beberapa informan, bahwa sebagian kecil ulama di nagari ini, cenderung mau menang sendiri. Terutama ketika terjadi perbedaan pendapat antara tokoh agama dengan masyarakat; Kedua,gaya komunikasi defensif suka menyerang lawan, lebih-lebih bila seorang komunikator ingin menutupi kelemahan. Gaya komunikasi defensive agaknya, dipengaruhi oleh power atau kekuasaan. Kekuasaan dalam kemampuan mengontrol apa yang terjadi, mengakibatkan munculnya hal-hal diinginkan terjadi, dan menghalangi hal-hal yang tidak dinginkan untuk terjadi. Argumen teoritisnya dan dan dipadukan dengan realitas di lokasi penelitian, bahwa ulama yang budaya Jawa, memilki 
kekuasaan untuk memenuhi kepentingannya sendiri dengan mengesampingkan tujuan-tujuan

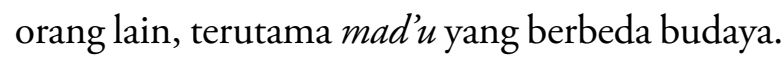
Dalam ulama yang mempunyai anggota budaya yang dominan, kadang mengalahkan anggota co-culture, yaitu etnis Minang dalam konteks berkomunikasi; Ketiga, gaya komunikasi menarik perhatian lawan bicara, dan penuh keramahan. Gaya seperti ini belum banyak dikuasai oleh para tokoh agama atau ulama di wilayah ini. Dalam kutbah jumat, pengajian dan kutbah idul fitri dan idul adha, para audience atau masyarakat belum menemukan komunikasi yang ramah, dan ditambah dengan materi yang kadang berulangulang, tanpa informasi yang baru, terkait dengan pelestarian nilai adat, budaya dan agama.

Akibat belum terdapat kompetensi komunikasi yang efektif lintas budaya, maka agama yang dianut oleh kedua etnis di Nagari Lunang, belum menjadi kekuatan integratif bagi masyarakat yang beragama, Padaha ajaran agama terdapat pesan afirmatif tentang keragaman manusia. Inti pesan agama adalah penegasan terhadap keragaman manusia, namun demikian pada prinsipnya adalah sama dan satu. Pemahaman seperti ini sebenarnya juga dipahami oleh masyarakat Lunang baik dari etnis Minang dan Jawa. Bahkan jika merujuk pada doktrin pluralisme Islam. Diciptakanya manusia dalam berbagai ragam, terkandung maksud untuk saling mengenal dan saling belajar. Jika menggunakan bahasa yang lebih retoris, agar umat manusia yang beragam itu mengembangkan dialog kebudayaan dan peradaban. Sayangnya realitas dilokasi penelitian, justru pemahaman keagamaan terhadap doktrin agama yang sama, berperan sebaliknya. Bahkan membangkitkan emosi suatu kelompok etnis untuk melakukan perlawanan terhadap kelompok etnis lainnya.

Perbedaan pemahaman tentang corak keragamaan dalam interaksi sehari- hari, diduga kerena terjadi distorsi dalam proses interaksionis simbolik antaretnis di Nagari, terutama yang berkaitan dengan dunia simbolik masing-masing etnis, dalam menafsirkan agama, yang belum disampaikan secara bijak oleh pemuka agama. Anggapan orang Jawa, terhadap etnis Minang bahwa budaya agamanya adalah budaya yang sudah ketinggalan dan sangat tradisional, dan hanya mengesankan baik, sementara jauh dari pengamalan. Termasuk falsafah adat basandi syarak, syarak basandi Kitabullah (ABS-SBK), hanya simbol formal, dan tidak nampak perbedaan pengamalan yang lebih bersifat religius setelah kembali kepada bentuk Nagari. Sedangkan stigma yang menimpa pada etnis Jawa, dalam beragama lebih menonjolkan simbol. Misalnya orang-orang Jawa banyak memakai topi hitam, akan tetapi tidak sholat, tidak pergi ke masjid kecuali hari raya dan sering berburu babi dan mengkonsumsinya.

Secara antropo-sosiologis fenomena di atas merupakan hal yang alami, namun tak pelak, bisa menjadi ancaman terhadap kelangsungan komunitas keagamaan yang dimiliki oleh etnis pribumi maupun etnis pendatang. Respon dari kedua kelompok masih menyimpan prasangka sosial, dengan tetap membiarkan perasaan curiga berjalan apa adanya dan seakan waktu yang akan menyelesaikannnya. Argumen teoritisnya, bahwa kondisi di atas, bila sewaktu-waktu ada pemicu lainya, seperti kesenjangan ekonomi, primordialisme budaya, solidaritas masing-masing etnis, ditambah lagi dengan provokator, akan 
berkembang dalam bentuk perlawan sosial yang lebih radikal yang didorong oleh sikap willingness to fight and die for in group (Colin Sumner, 1987). Apalagi konflik tersebut dicarikan legitimasi pada pemahaman agama yang reduktif, yakni sebagai pertahanan harga diri dalam memahami agama dengan pemahaman etnis lain, maka akan semakin memperuncing, memperdalam dan memperluas pertentangan antaretnis. Sebenarya bila diruntut dalam wacana Islam Indonesia, terdapat berbagai tradisi keagamaan lokal yang pada dasarnya merupakan hasil interaksi antara Islam sebagai tradisi besar dengan budaya lokal sebagai tradisi kecil (M. Bambang Pranowo, 1999). Hasil interaksi tersebut tidak menyinggung hal-hal yang substansi dalam agama, hanya hal-hal cabang semata.

Agama yang dianut oleh masyarakat Lunang hanya satu, yaitu Agama Islam, hal ini sebenarnya lebih memudahkan dalam program Pemerintah Propinsi dalam rangka pelestarian nilai adat, budaya dan agama. Organisasi keagamaan yang berkembang diantaranya Jamaah Tabligh dengan pusat kegiatan di Kampung Tanjung Beringin II, di Masjid Baitul Makmur, Tariqat Naqsabandiyah dan Qadiriyah di kampung Talang Sari II dengan pusat kegiatan pada Mushala Muslimun yang dipimpin oleh K. H. M. Nanang Abdullah. Organisasi yang dominan adalah Nahdhatul Ulama (NU) bagi etnis Jawa dan Muhammadiyah bagi etnis Minang pendatang. Uniknya, etnis Minang pribumi mempunyai tradisi tersendiri dalam pemahaman agama, yaitu pemahaman Islam yang terkatagori tradisional tetapi tidak mengelompokkan diri pada organisasi pada umumnya baik NU, Tarbiyah Islamiyah, maupun Muhammadiyah. Di sinilah sesungguhnya letak perbedaan pemahaman dan ekpresi keagamaan antaretnis pendatang dan pribumi. Letak perbedaan tersebut adalah perbedaan dalam menentukan awal puasa dengan malam takbiran dan hari raya Idul Fitri. Etnis pendatang untuk penentuan awal puasa, mengikuti aturan dan keputusan pemerintah, sedangkan bagi pribumi awal puasa ditentukan, ketika sudah melihat bulan dengan jelas, hal ini menyebabkan jatuhnya 1 Syawal selalu berbeda dengan etnis pendatang.

Dari uraian sepintas di muka, logikanya sederhana saja, bahwa konflik pemahaman yang terjadi, dilatarbelakangi oleh situasi komunikasi dalam konteks ekpresi keberagamaan yang kerap kali mengalami hambatan, dalam arti terjadi perbedaan dalam memaknai pesan yang saling mereka pertukarkan. Misalnya saja terjadi perbedaan penafsiran dalam penggunaan wacana ABS-SBK, lambang-lambang, nilai atau normanorma dalam organisasi keagamaan masingmasing etnis di nagari Lunang. Padahal syarat untuk terjalinya interaksi sosial yang baik, tentu saja harus ada saling pengertian dan persamaan makna pesan antara satu dengan lainnya, dalam hal ini tokoh agama atau ulama dengan masyarakat.

\section{KESIMPULAN}

Berdasarkan penyajian dan analisis data dari pembahasan sebelumnya, artikel ini berkesimpulan bahwa perbedaan budaya berimplikasi terhadap komunikasi ulama lintas budaya. Hal itu dilatarbelakangi oleh: Pertama, faktor pengetahuan yang terdiri dari Nilainilai budaya, pandangan dunia, sejarah, dan organisasi sosial, yang dianut masing-masing etnis, mempengaruhi kompetensi komunikasi ulama lintas budaya pada aspek pengetahuan dalam 
kontek pelestarian nilai budaya, adat dan agama. Secara konseptual, hasil penelitian ini mendukung teori komunikasi antarbudaya yang dikemukakan oleh William B. Gudykunst dan Young Yun Kim, bahwa dalam komunikasi antarbudaya manusia selalu dipengaruhi oleh sistem kultural, sosiokultural dan psikokultural.

Kedua, ketidakmampuan mengurangi kesalahpahaman budaya merupakan faktor penghambat kompetensi komunikasi ulama lintas budaya pada aspek motivasi. Secara konseptual temuan penelitian ini, menguatkan teori Larry. A. Samovar, Richard E.Porter dan Edwin R. McDanel; Ketiga, gaya komunikasi yang mau menang sendiri, defensive dan kurang ramah, meruapakan faktor penghambat pada aspek keterampilan berkomunikasi ulama lintas budaya. Temuan ini mendukung teori negosiasi identitas yang dikemukan oleh William B.Gudykunts.

\section{DAFTAR PUSTAKA}

Abdullah, Amin. (2003). Arah Baru Kajian Islam. Makalah dipresentasikan pada acara Seminar Annual Comperence, Yogyakarta.

Abdullah, Taufik. (1972) "Modernization in the Minangkabau World: West Sumatera in the Early Decades of $20^{\text {th }}$ Century” . Claire Holt (Ed.). Culture and Politics in Indonesia. Ithaca. New York: Cornell University Press.

Anan, Gusni. (2003). Penguasa Militer dan Pemerintahan Daerah: Sumatera Barat Akhir 1950 dan Awal 1960-an. Jurnal Analisis CSIS, No. 4.

Asa Berger, Athur. (2000). Media and Comunication Research Methods: An
Introduction to Qualitative and Quantitatif Approaches. London: Sage Publications.

Bogdan, Robert C. and Biklen, Sari Knopp. (1982). Qualitative Research for Education: An Introduction to Theory and Methods. Boston: Allyn and Bacon Inc.

De Vito, Joseph A. (1981). Communication: Concepts and Processes. New York: PrenticeHall.

Endraswara, Suwardi. (2006). Metode, Teori Teknik Penelitian Kebudayaan: Ideologi, Epistemologi, dan Aplikasi. Yogyakarta: Pustaka Widyatama.

Geung, Kim. (2004). Komunikasi Antarabudaya Korea dan Indonesia (Kajian tentang Perilaku Masyarakat Korea dan Jawa). Yogyakarta: Pusat Studi Korea UGM.

Gibb, Jack. (1961). Devensive Communication. Journal of Communication Volume 11.

Gladstein, Gerald A. (et al.). (1987). Empaty and Counseling: Ecploration in Theory and Research. New York: Spinger-Verlag.

Gudykunst, William B. and Yun Kim, Young. (1992). Communicating With Stagers An Approach To Intercultural Communication (Ed.). USA: McGraw-Hill.

Gudykunst, William B. (et al.). (1996). Communication In Personal Relationship Across Cultures. USA: Sage Publications, Inc. Gudykunst, William B. dan Mody, Bella. (2002). Handbook of International and Intercultural Communication (Second Edition). California: Sage Publication Inc. 
Hamad, Ibnu. (2006). "Teori Analisis Wacana," Hand Out, (Tidak diterbitkan), Jakarta: Pascasarjana FISIP UI.

Kirk, Jerome and L. Miller, Marc. (1986). Reliability and Validity in Qualitative Research. Beverly Hills: Sage Publications.

Kusmana. (2006). Integrasi Keilmuan UIN Syarif Hidayatullah Jakarta menuju Universitas Riset (Ed.). Jakarta: Kerjasama PPJM dengan UIN Jakarta Perss.

Lincoln, Y. Vonna S. dan Guba, Egon G. (1985). Naturalistic Inquiry. Beverly Hills: Sage Publications.

Littlejonh, Stephen W. (1996). Theories of Human Communication. California: Wadsworth Publishing Company.

Marshall, Catherine and B. Rossman, Gretchen. (1989). Designing Qualitative Research. California: Sage Publications. Inc.

Matsumo, Yoko. (et al.). (1996). Cross-Cultural Variabilty of Communication in Personal Relationships. Gugykunts, William B. Communication in Personal Relationships Across Culture. California: Sage Publications Inc.

Meleong, Lexy. (2000). Metodologi Penelitian Kualitatif. Bandung: Rosdakarya.

Muarif Ambary, Hasan. (1998). Menemukan Peradaban Arkeologi dan Islam di Indonesia. Jakarta: Arkeologi Nasional.

Muhadjir, N. (1989). Metodologi Penelitian Kualitatif: Telaah Positivistik Rasionalistik dan Phenomenologik. Yogyakarta: Rake Sarasin.
Muhammad Amin, Miska. (1993). Epistemologi Islam. Jakarta: UI Press.

Mulyana, Dedy. (2001). Metodologi Penelitian Kualitatif Paradigma Ilmu Komunikasi dan Ilmu Sosial Lainnya. Bandung: Remaja Rosdakarya.

Nasikun. (2003). Fenomenologi, Makalah disampaikan pada Pelatihan Penelitian Dosen-dosen STAIN se-Indonesia. Salatiga.

Norman K, Denzin dan Y.Vona S. Lincoln. (1994). Handbook of Qualitative Research (Ed.). California: Sage Publications, Inc.

Pranowo, M. Bambang. (1999). Islam Faktual Antara Tradisi dan Relasi Kuasa. Yogyakarta: Adicita Karya Nusa.

Quin Patton, Michael. (1990). Qualitative Evalutions and Research Methods. Newbury Park: Sage Publication.

Ramadhan Yusuf, Muhammad Khair. (1990). Min Khashẩish al-I'lâm al-Islâmî. Mekah: Rabithah 'Alam Islamiy.

Sambas, Sukriadi. (2004). Struktur Keilmuan Dakwah. : Makalah disampaikan pada Seminar Pengembangan Ilmu Dakwah. Jakarta.

Samovar, Larry A. (et al.). (1985). Understanding Intercultural Communication. Belmon California: Wadsworth Publishing Company.

Samovar, Larry A. (et al.). (2006). Communication Between Cultures. California: Wadsworth Publishing Company.

Sanderson, Stephen K. (1991). Sosiologi Makro: Sebuah Pendekatan terhadap Realitas Sosial (edisi Indonesia). Jakarta: Raja Wali Press. 
Schoorl, W. (1993). Culture and Change Among the Muyu. Leiden: KITLV Press.

Schroedev, Ralph. (t.th). Max Weber and The Sociology of Culture. London: Sarge Publications, t.th

Sobur, Alex. (2006). Semiotika Komunikasi. Bandung: Rosdakarya.

Soeprapto, H. R. Riyadi. (2002). Interaksionis Simbolik: Perspektif Sosiologi Modern. Yogyakarta: Averroes Press Bekerjasama dengan Pustaka Pelajar.

Spitzberg, B. and Cupach, W. (1984). Interpersonal Communication Competence. New York, Sage Publication.

Strauss, Anselm L. and Corbin, Juliet. (1990). Basic of QualitatifResearch, Grounded Theory Procedure and Techniques. London: Sage Publication.

Sumner, Colin. (1978). Violence, Culture dan Censure. London : Taylor \& Francis.
Tamzirien. (2008). Serat Dewaruci: Gelora Sufisme Islam Jawa. (Edisi V. Tahun I.). Jakarta: Kartika Press, 2008.

Tatang M, Amirin. (1990). Menyusun Rencana Penelitian. Jakarta: Rajawali Pers.

Tim Peneliti. (2005). Peta Dakwah Sumatera Barat. Padang: Kerjasama Pemda Sumbar dengan Fakultas Dakwah.

Tumanggor, Rusmin. (2003). Acuan Dasar Proposal Penelitian: Refleksi atas Pelbagai Proposal. Narasi, Vol. IV.

W. Creswell, John. (1998). Qualitative Inquiry and Research Design: Choosing Among Five Tradition. London: Sage Pullications.

Yun Kim, Young. (1991). Intercultural Communication Competence: A SystemTheoritic View”. S. Ting Toomy dan R. Korzenny (Ed.). Cross-Cultural Interpersonal Communication. Newbury Park, CA: Sage Publications. 